\title{
A Political Paradox: The Common Franchise Question and Ethnic Conflict in Fiji's Decolonisation ${ }^{1}$
}

\author{
Robert Norton
}

The moral vision that has shaped my interpretation is essentially modernist, democratic, and egalitarian. I will not contest that my approach is necessarily more justified or better than others with different points of departure. Value is a matter of judgment, and there can be no question of finality in scholarly discourse.

Brij V. Lal (1992: xvii-xviii)

Unless history displays conviction, interest, and involvement, it will not be understood or attended to. That is why subjective interpretation, while limiting knowledge, is also essential to its communication ... History is persuasive because it is organized by and filtered through individual minds, not in spite of that fact. Subjective interpretation gives it life and meaning.

David Lowenthal (1985: 218)

The engaging qualities we enjoy in Brij Lal's work were evident in one of his first publications - a lengthy paper on the indenture system in Vijay Mishra's edited volume marking the centenary of the first arrival of indentured Indians in Fiji (Lal 1979: 12-39). I vividly recall my first

1 Some statements in the present chapter are drawn from Norton (2015). 
meeting with Lal that year at a lunch at Macquarie University with Chandra Jayawardena, my intellectual mentor and professor, who also had written a chapter on the indenture system for that volume. I found myself siding with Lal's redemptive concern in his paper as Jayawardena indulged in some light-hearted needling that I thought was a bit tough on this bright young scholar newly venturing on the academic stage. The hint of rivalry from the eminent senior scholar was further indication of Lal's calibre.

The involvement and conviction in Lal's writing express his deep personal commitment as grandson of an indentured worker and his interest, driven by postcolonial Fiji's traumatic political events, in counterfactual questions about what might have been. One of his major concerns has been with the decisions and events of the 1960s when British officials worked with political leaders to prepare Fiji for independence. Running through much of Lal's writing is the question: how might that process have been better conducted to lay foundations for a less troubled and more prosperous multiethnic Fiji?

I share Lal's interest in the decolonisation decade. I began my research in Fiji at that time and like him I have studied the official documents on the process of ending British rule. We have often exchanged ideas and sometimes disputed about the events and personalities of those years. In this chapter I want to take our discussions further, proceeding in the spirit of Lal's declared openness to alternative historical interpretations and his interest in counterfactual possibilities. I will first reexamine the course of political decisions and events, giving critical attention particularly to the principal Indian leaders' militant push for a common franchise. I will conclude by considering what decisions could plausibly have been taken by British colonial officials and Fiji's political leaders that might have averted the political difficulties and traumas that have beset Fiji since independence.

The question of how the electoral system should be reformed was the major issue of contention among Fijis political leaders during decolonisation. Lal and some other writers on Fijis modern history have maintained that the failure of the British rulers to introduce a common electoral franchise to replace the system of communal representation is substantially to blame for postcolonial Fijis recurrent political violence and instability. The leading advocate for a common franchise in the 1960s was the India-born barrister A.D. Patel (1905-1969), founding president 
of the National Federation Party (NFP). ${ }^{2}$ In a compelling biography, Lal details Patel's outstanding contributions to political leadership and debate in late colonial Fiji (Lal 1997). I share Lal's admiration for Patel, whom I knew and observed at election rallies. Powerful in intellect and personality, Patel was an eloquent exponent of his vision of an integrated, multiethnic nation. The most formidable lawyer and debater in the Fiji of his day, he was a tireless advocate for social and economic as well as political reforms. I cannot agree, however, that his campaign for a common franchise, in the militant way in which he and his NFP colleagues conducted it, was a positive factor for Fiji's political development in those critical years. Mistaken actions were taken, with harmful long-term consequences, by these leaders no less than by their political opponents and British colonial officials. I shall argue that the ethnic political polarisation in the 1960s was determined far less by the communal electoral system than by the militant campaign for its replacement by common electoral rolls and non-reserved parliament seats.

Studying the politics of a society so ethnically divided as Fiji at the time of its decolonisation, is likely to engender in a western scholar a tension between personal universalist social values and an understanding of deepseated social and political realities that clash with those values. This has been my own experience in writing about Fiji. As a young researcher in the mid-1960s, imbued with the tenets of 'modernisation theory', I readily identified with the radical Indian leaders' ideology and attended more to their views and activities than to those of their opponents in the Alliance Party. That ideology made for the most compelling campaign rhetoric against the dull conservatism of the latter's discourse. But I also met frequently with Fijian leaders in the Alliance Party and attended some of their campaign gatherings in villages, gaining insight into the depth of Fijian opposition to the NFP's common franchise call. A standout feature of election campaigning at that time was a stark disjunction between the content and militant style of the NFP rhetoric and the indigenous Fijian perceptions and fears. I came to view the NFP's campaign for radical reform as an error of political judgement. Developing a balanced system of multiethnic political parties or coalitions and avoiding a strengthening of ethnic tension should have been the main objective in the decade

2 Originally named Federation Party, after the federation of sugar cane farmers' unions upon which it was initially built, the party was renamed National Federation Party (NFP) in 1968 when a small indigenous Fijian party joined it. For simplicity I will refer to the party as the NFP throughout the chapter. 
of decolonisation. The push for a common franchise deepened the ethnic political divide and prevented the NFP from building a multiethnic alliance that might actually have proved more conducive to an agreement with its opponents for some reform in the direction it sought.

\section{The politics of decolonisation}

By the mid-1960s, Fiji's politics centred on rivalry between the NFP and the Alliance Party (Alley 1986: 28-51; Norton 1990: 75-106). ${ }^{3}$ The interests and outlooks of the leaders had been shaped in very different social domains. The NFP's founders achieved popularity initially by their leadership of Indian sugar cane farmers in conflict with the Australianowned Colonial Sugar Refining (CSR) Company. As the party extended its reach beyond the sugar districts, on the issue of Indian rights, its leaders and key supporters included lawyers, teachers, businessmen and trade unionists. It campaigned as a disciplined heroic body challenging colonial power. British officials, the NFP alleged, were resolved to end their rule with constitutional changes preserving the privileges and power of Europeans and their allies, the leading Fijian chiefs. ${ }^{4}$ A.D. Patel, the NFP president, was inspired partly by the anticolonial history of India's Congress Party, which he had observed as a young man (Lal 1997: 107, 112-13). Three of the 12 NFP Indian candidates in the 1966 elections, including Patel, had grown up in India. Among the strongest supporters were many more who had come of age there, especially Patel's friends and associates in the Gujarati business community.

The Alliance Party was formed against the NFP as a coalition of indigenous Fijian, Indian, European and other groups. The leaders of its major body, the Fijian Association, were mainly several high-ranking Fijian chiefs who headed the colonial system of village administration that restricted most Fijians to only marginal engagement with the modern economy. These men had developed salaried and political careers in colonial bureaucracies. They clung defensively to their European political allies and were initially apprehensive about the ending of colonial rule.

\footnotetext{
3 Roderic Alley's excellent $\mathrm{PhD}$ thesis is the most detailed study (Alley 1976).

4 When speaking of 'the British', I refer to the UK government officials in Fiji or London. I use the term 'Europeans' as it is applied in the Fiji census to refer to white residents of Fiji, both citizens and temporary residents; predominantly of British ancestry, they or their forebears were mostly from Australia or New Zealand.
} 
There was a paradoxical contrast in the contention about the electoral system. The NFP affirmed a universalist ideology and called for abolition of communal representation to affirm equality among the citizens and encourage national integration. Yet it remained essentially communal in its leadership and its following with frequent appeals to communal sentiments. The mainly Fijian-supported Alliance Party emphasised the strength of ethnic differences and the potential for destructive conflict. It insisted on the preservation of a communal electoral system to secure indigenous Fijians against the possibility of Indian dominance and thereby to ensure political stability. Yet the Alliance had significant success in building multiethnic leadership and support.

In the early 1960s, most Indian political leaders had adopted a moderate stance on constitutional issues, causing the colonial secretary to remark in a report to London late in 1963 that they were 'leaning over backwards to cooperate with both government and the Fijians. 5 The common franchise question was not a major issue in the 1963 Legislative Council elections (Meller and Anthony 1968: 71). The change to a demand for radical electoral reform followed the launching of the NFP in mid-1964, a year after the first UN resolution pressuring Britain to end its rule over Fiji. ${ }^{6}$ Four years earlier, the party's founders led a harvesting boycott by sugar cane farmers against the CSR Co. ${ }^{7}$ Several Fijian, European and Indian political leaders had persuaded most Fijian growers to withdraw from the strike. Their conflict with the militant strike leaders contributed to the tension that grew as Britain moved Fiji toward self-government, for the two groups became the principal antagonists in the contention over constitutional reform.

Indian leaders had first called for a common franchise in the $1920 \mathrm{~s}$ when only Europeans enjoyed elected representation in the colonial legislature. ${ }^{8}$ The British officials refused to make the reform, arguing that it would lead to an Indian political strength that would imperil their

5 Macdonald to Marnham, National Archives (Kew), Records of the Colonial Office (hereinafter CO), 15 October 1963, CO1036/1263. See also Norton 2002: 145-46.

6 'Declaration on Independence for Colonial Countries and Peoples: The Situation With Regard To The Implementation Of The Declaration On Granting Independence To Colonial Countries And Peoples'. In The Yearbook of the United Nations 1963: 450, 456.

7 The strike was marked by some violence and arson attacks and army reserves were sent to protect farmers who wished to harvest their cane.

8 Indigenous Fijians were represented by nominees of the Council of Chiefs. Indian political leaders did not include Fijians in their argument for a common franchise until Fijians were enfranchised in 1963. 
ability to safeguard the interests of the native Fijians (Lal 1992: 90-91). The Europeans insisted that political representation far out of proportion to their numbers was justified by their economic importance and their sharing with colonial officials the role of guardians of the Fijians. The Indians were given only three elected seats beside the Europeans' six. In protest their leaders boycotted the legislature for several years. The issue was soon eclipsed, however, by their concern with questions of education and lease access to Fijian land.

The call for common electoral rolls for Indians and Europeans was revived in the 1950s as Britain proceeded with decolonisation elsewhere. Britain's declaration a few years later of the plan to end its rule of Fiji, and United Nations pressure for this, encouraged a stronger push by Indian leaders for radical change, which brought them into acrimonious conflict with Fijian and European leaders of the Alliance Party. The latter agreed that a common franchise should be the long-term goal but insisted that social integration and a reduction of economic disparities must come first.

Several factors encouraged indigenous Fijian hostility to the common roll proposal. Especially since the 1940s, Fijians had feared a threat of Indian political domination and the decision to prepare Fiji for self-government alarmed them with the prospect of losing colonial protection. Their apprehension was deepened by the United Nations pressure on the UK to grant Fiji independence with a common franchise; they feared that the British might acquiesce and that Fijian interests, particularly their lands, would be in jeopardy. Until 1963, Fijians had not experienced electoral politics but were represented in the legislature by nominees of the Council of Chiefs. Most Fijians were subsistence villagers acutely conscious of Indian demographic, economic and educational superiority. ${ }^{9}$ They had been encouraged by their leaders to view the hardline stand of the NFP leaders in the sugar dispute of 1960 as a threat to Fiji's stability and prosperity and a demonstration of those leaders' irresponsibility. Many Fijians believed allegations that the Indians aimed to drive out the CSR Co. and take control of the industry.

The extension of the franchise to Fijians compelled their political leaders to devise rhetoric for competition with new Fijian leaders emerging in the trade unions and the urban middle class. The established leaders stressed

9 Indians were nearly 51 per cent of the population, Fijians 43 per cent. Although the difference in population growth rate was lessening, the Indian rate was still substantially greater than the Fijian. 
the need to promote Fijian unity to counter the risks that decolonisation would bring, particularly the threat of Indian dominance and their alleged objective of severing Fiji's link with the British Crown. The Fijian leaders were supported by European politicians, foremost of whom, John Falvey, sat with them as legal adviser on the Fijian Affairs Board. ${ }^{10}$ This alliance was conspicuous at the first constitutional conference in London in 1965 where the Fijian delegates would not talk freely with the British officials until the officials agreed to meet them with the European delegates. ${ }^{11}$

The NFP's common franchise call had an inflammatory impact on the Fijian mood. Just as it helped to draw a large majority of Indians to the NFP, equally it helped mobilise most indigenous Fijians behind the Fijian Association and the Alliance Party. The Fijian Affairs Board chiefs making the transition from the security of their authority in the Fijian Administration and the Council of Chiefs to popular elections were advantaged by the NFP campaign they denounced. The Indian radicalism strengthened their popular relevance when social and economic change had been encouraging dissatisfaction with them.

The NFP campaign developed aggressive momentum as it extended beyond the sugar districts. With righteous fervour, the leaders promoted the party as a moral authority defending Indian rights and they condemned Indian opponents as traitors to their community. The demand for a 'common roll' ('one man, one vote, one value') was made the party's war cry and the symbol of its claim to legitimacy in Indian leadership. The primary objective, emphasised in campaign rhetoric, was to show the UK and the UN that the Indians were united behind the party. Electoral support grew from 64 per cent of Indian votes in 1966 to 77 per cent in 1968. But throughout the 1960s and beyond, it attracted only very weak and unstable indigenous Fijian support.

\section{International and domestic political arenas}

The militant push for a common franchise must be understood in relation to the universalist values central to the vision of social and political modernity that the United Nations was committed to uphold.

10 Since the 1920s, Europeans had nurtured their alliance with the leading Fijian chiefs to strengthen their own position against the Indian demand for political equality (Norton 1990: 37-40).

11 Trafford Smith to Jakeway, 17 August 1965, CO1036/1119. 
NFP leaders hoped that the new Labour Party government in the UK (1964-1970), under UN pressure and recognising that the NFP was the major voice of 51 per cent of Fiji's population, would favour the demand for political equality. They especially valued the support of India, which, through most of the 1960s, was one of the severest critics at the UN against British colonial power.

The decision for a militant campaign was taken in the context of the importance of these external political agents. The NFP saw in them the prospect of persuading a reform that would ensure the Indians' security when self-government came. ${ }^{12}$ This hope, together with the imperative to strengthen the NFP's dominance in Indian leadership, discouraged the party from compromising with its Alliance Party opponents. There appeared to be little incentive for moderation in the face of the Fijian and European resistance to radical change. Yet that resistance was the domestic political reality with which the NFP had eventually to come to terms near the end of the decade after an intimidating display of indigenous Fijian anger.

The NFP leaders' hope for international support was influenced also by the fact that they had fewer avenues for building a multiethnic following than did their Fijian counterparts, regardless of the political issues. Interests that sometimes encouraged some Fijians to unite with Indians in industrial disputes were submerged when ethnic concerns came to the fore. In the political arena there was, too, the old Fijian perception of Europeans as their protectors united with the chiefs in the face of the numerically and economically stronger Indians. The established pattern of political loyalties and alliances in Fiji helped induce the radical Indians to appeal to external agents on constitutional matters and to disregard pressures to compromise with Fijians and Europeans at home.

\section{The constitutional talks of 1965}

The NFP's reliance on perceived opportunities in the international political arena was reinforced by an impasse in discussions in Suva with their Fijian and European counterparts initiated by the colonial governor

12 British officials believed Patel was directly influencing the UN in the mid-1960s, although there was little firm evidence of this (Lal 2006: lxviii). British delegates to the UN found no evidence of attempts to influence UN delegates in the late 1960s. Shaw to Lambert, 7 March 1969, The National Archives (Kew), Records of the Foreign and Commonwealth Office (hereinafter FCO), FCO58/314. 
early in 1965 in preparation for the first constitutional conference in London. The NFP leaders' withdrawal from the talks was provoked by leaks to the European-controlled media, which published articles allegedly deliberately misrepresenting the party's leaders and their common roll agenda 'with the object of creating animosity, misunderstanding and disharmony'. ${ }^{13}$ The NFP leaders were convinced that the Fijians and Europeans were implacably set against compromise. ${ }^{14}$ The Fijian leaders and the governor were angered by the Indians' action, particularly as they were hoping for some sympathy for 'the Fijian position over constitutional matters in return for the Fijians' declared willingness to meet the Indians wish for greater security of land tenure. ${ }^{15}$ Ratu Mara feared that 'without an indication of Indian willingness to compromise on such basic issues as common or communal rolls', he would find it very difficult to persuade the Council of Chiefs to agree to the new landlord and tenant proposals. ${ }^{16}$ The tension arising from the failure of dialogue in Fiji was aggravated by the outcome of the London conference.

In planning Fijis decolonisation, the British did initially favour replacing the communal electoral system with a common franchise, but soon concluded that this would risk political upheaval and ethnic violence that they might not be able to control, particularly as Fijians predominated in the army and police. ${ }^{17}$ Concerned especially about the Fijian anxiety, the British delegates approached the constitutional conference resolved to make only very limited reforms of the electoral system. They offered a proposal, already discussed with officials in Fiji, which they argued would take a first step toward a common franchise by encouraging some voting across the ethnic divides but without removing ethnic reservation of seats. There would be three multiethnic ('cross-voting') electorates together covering the entire colony, each with a Fijian seat, an Indian seat, and a General Electors seat. Most electorates would continue to be

13 Annual general meeting of the Federation Party, Lautoka, 25 April 1965. Papers of A.D. Patel, Pacific Manuscripts Bureau microfilms, PMB 1152, reel 1. On the Suva talks see Lal 1992: 195-200; Alley 1976: 73-82; Scarr 2009: 130-134.

14 After withdrawing from the Suva talks, Patel sought private meetings with the principal Fijian and European leaders, Ratu Mara and John Falvey. Mara, fearing criticism from Fijian colleagues, asked Falvey to represent him. Patel declined to proceed in this circumstance. Robert Norton, taped interview with Patel, 31 October 1966. In Suva, before the London conference, the governor urged on the Fijian and European leaders the wisdom of taking a step toward a common franchise (Norton 2002: 148-49).

15 Jakeway to Trafford Smith, 8 April 1965, CO1036/1283.

16 Jakeway to Secretary of State, 17 March 1965, CO1036/1283.

17 Draft Colonial Office report on the conference for Foreign Office (undated), CO1036/1119. 
ethnic (communal) in composition. The 'cross-voting' electorates were to comprise combinations of ethnic electorates. Every elector would belong to both an ethnic electorate and a multiethnic one and thus be entitled to four votes.

With difficulty, the British officials persuaded the six Fijian and six European conference delegates to agree to this innovation. But five of the six Indians held out for a full common franchise without reserved seats, refusing to offer a compromise until near the end of the conference when they suggested some common roll seats in addition to communal and cross-voting seats. The British officials were agreeable to this but the Fijians and Europeans could not be swayed. The Indians were aggrieved less by the rejection of their proposal than by the granting of 10 seats to the new category of General Electors (Europeans, Part-Europeans and Chinese) representing only 4.5 per cent of the population, and by the 14 seats given to Fijian electors (now including non-Fijian Pacific Islanders who with the indigenous Fijians formed 45 per cent of the population), while the Indians (51 per cent of the population) were allowed only 12 seats. The longstanding parity of representation had ended. ${ }^{18}$

The Indians returned to Fiji embittered and angry, disillusioned with the failure of the British to meet their expectation for sympathetic treatment: 'we are all bitterly disappointed and in a state of emotional tension', Patel told a BBC interviewer immediately after the conference. ${ }^{19}$ The British delegates were deserving of criticism for not insisting on at least a more equitable outcome, as were the Fijians and Europeans for their refusal to agree at least to a trialling of some common roll seats. ${ }^{20}$ The NFP Indians,

18 From 1937 until 1966, Fijians, Indians, and Europeans sat in equal numbers on the unofficial side of the Legislative Council. On the 1965 constitutional conference, see Alley 1976: 81-90; Lal 1992: 195-200; Lal 2006: lxiff; Scarr 2009: 136-40.

19 National Archives of Fiji (hereinafter NAF), CSO transfer file, 5/26/1. The Indian delegates had protested to the secretary of state for colonies urging that the proposals for the new constitution be amended as they would 'create grave racial disharmony' and 'irreparable harm ... to the country' (Letter to Greenwood, 12 August 1965, CO1036/1131). Greenwood responded that opposing the new constitution was 'likely to increase the suspicions of the other communities' and that cooperation in the introduction of the new constitution would help 'pave the way to further constitutional progress' (Greenwood to Patel 9 September 1965. In Papers of A.D.Patel, Pacific Manuscripts Bureau (PMB) 1152, Reel 1 'Letters ...'. Greenwood misidentified as 'Freeman' in contents list). After the conference, a senior London official and the Fiji governor tried, separately, to persuade the Fijians and Europeans to agree to the Indians being given an additional seat or two. Secretary of State to Jakeway, 9 August 1965, CO1036/1119; Jakeway to Trafford Smith, 16 November 1965, CO1036/1054.

20 The governor was later to say privately that the Fijians and Europeans had been 'too greedy'. Australian High Commissioner reporting discussions with Jakeway, Hamilton to External Affairs Canberra, 17 October 1966, National Archives of Australia (hereinafter NAA), A1838 316/1/6 part 6. 
too, were at fault in maintaining a rigid stance for a full common franchise until close to the conference end after the Fijians and Europeans had very reluctantly agreed to the cross-voting proposal. The British delegates lamented that the NFP men had come to the conference only with a 'largely theoretical' argument for the common franchise but without a negotiating strategy for responding effectively to the Fijian and European opposition to such a reform; a failing that allegedly demonstrated their lack of understanding of Fiji's political realities. ${ }^{21} \mathrm{Had}$ the Indians made more realistic preparation for negotiation, the British said, they would probably have made some gains.

It was a poorly conducted and badly concluded conference that provoked a worsening of political and ethnic tension over the next three years, culminating in a dangerous crisis of ethnic conflict. The new constitution did, however, bring a major reform welcomed by all: a majority of nonofficial seats in the Legislative Council. The official side was reduced from a slight majority to just four out of 40 seats; 34 seats would be filled by popular election and two by Council of Chiefs' nominees. The next Legislative Council elections were the first in which political groups could compete for substantial influence in government.

\section{The 1966 elections and the advent of Alliance Party Government}

The highpoint of UN pressure on Britain over the Fiji question came in 1966. For the first time the colony was made a separate item on the General Assembly's agenda. The uncompromising UN resolutions were closely in tune with NFP election rhetoric. Town rallies with brilliant orators denouncing colonialism, especially its alleged injustices to Indians, mobilised an excited Indian public on an unprecedented scale. There were frequent declarations that the UN and 'world opinion' would compel Britain to introduce the common franchise and that this must be the 'last will and testament' of British rule. To speed reform, the NFP said, the UN

21 Trafford Smith to Jakeway, 20 August 1965, CO1036/1131. Fiji's governor had sent to London a lengthy report on the NFP that asserted 'there is little doubt that the long-term aim [of the NFP leaders] is to secure the political and economic domination of Fiji by the Indians'. It suggested that if the conference 'results in a ... constitution whereby ... Fijians and Europeans collectively outnumber the Indians in the Legislative Council, it will not be easy for the Party leaders ... to pursue their ambitions'. Jakeway to Secretary of State, 29 June 1965, CO1036/1125. It is not known if this advice influenced British government delegates to the conference. 
was appointing a committee for an inspection visit to Fiji. ${ }^{22}$ Britain must allow this, especially as the elections will prove the NFP is the voice of the Indians. And Britain must implement recommendations arising from the inspection that would undoubtedly back the NFP demand.

The Alliance Party's theme was that it alone had multiethnic support and leadership and aimed to build harmony and prosperity by preserving the communal electoral system to secure the interests of the different ethnic groups, particularly the indigenous Fijians. The Alliance would govern responsibly in the interests of all, whereas the NFP was a communal party whose radical electoral reform agenda was a threat to all. Moreover, its leaders had demonstrated their irresponsibility by their militancy in the sugar industry strike and by their withdrawal from the Suva talks. To its Fijian audiences, the party's Fijian candidates gave assurances that an Alliance victory would ensure that Fijians held political power when self-government came.

The Alliance Party dominated the new Legislative Council. It had won all 12 Fijian seats (attracting 66 per cent of the votes in the communal electorates), seven of the 10 General seats, and the three Indian seats in cross-voting electorates (but attracted only 15 per cent of the votes in the communal Indian electorates). In addition, the Alliance was supported in the Legislative Council by the two Council of Chiefs nominees and all three independent General members. The NFP secured only the nine communal Indian seats (with 64 per cent of the votes) and fielded only one non-Indian candidate (a Fijian cane farmer in a predominantly Indian electorate) (see Norton 1990: 75-106; Alley 1976: 176-264).

Given the strength of Indian support for the NFP, the governor, Sir Derek Jakeway, urged Ratu Mara, the Alliance president, to share with Patel the non-official seats in a new Executive Council. Mara, with his principal European ally John Falvey at his side, objected that this would upset his Indian colleagues and that in any case the parties were ideologically incompatible. Mara, Falvey and Patel had sat together in the Executive Council since 1964, and Jakeway was hoping to maintain an ethnic balance

22 This was true. See 'The situation with regard to the implementation of the Declaration on the granting of independence to Colonial Countries and Peoples: Fiji.' In The Yearbook of the United Nations 1966: 578-81. The UN request to inspect Fiji was refused by the British on the ground that such a visit was 'unnecessary'. The Fijian and European leaders firmly rejected the proposal. 
among the non-official members. ${ }^{23}$ But he had also resolved to nurture Mara to become Fiji's first prime minister and now readily accepted his argument, later stressing to London that it was Mara's decision 'to proceed with party political government'. ${ }^{24}$ In his end-of-year report to London, Jakeway enthused about Mara's leadership, declaring that 'very soon we will have a situation of virtual self-government' and that now the governor 'can only exercise influence'. 25

Patel claimed at a party rally that he was invited to join the government but had refused in order to better serve the people as leader of the opposition. Privately he was aggrieved at the governor's decision and his resentment deepened as it became clear over the following months that Jakeway was content to allow Mara and his Alliance colleagues much rein in government. This situation was strengthened by Jakeway's introduction of the ministerial system in September 1967. ${ }^{26}$ In his January 1968 report to London, Jakeway declared that 'the Alliance offers the best prospect of stable non-partisan government in Fiji and continues to deserve the support it has received from Her Majesty's Government'. ${ }^{27}$

\section{Political crisis and conciliation}

Patel judged the governor's decisions and London's ready approval to signify official disinterest in considering further change as a matter of any urgency. Angered especially by the governor's failure to consult him about the ministerial appointments, he condemned the constitution as

23 Reporting to London on the eve of the elections, Jakeway had said 'a coalition government works best': 'A system of "Government" and "Opposition" is too likely to stratify on racial lines ... It is our object to foster the seeds of union ... They are there but need careful nurture ... I only hope that they will still be there to tend after the elections'. Jakeway to Secretary of State, 12 July 1966, National Archives, Dominions Office (hereinafter DO), DO169/501.

24 Jakeway to Trafford Smith, 14 August 1967, FCO60/34. The governor retained 'full powers in respect of defence, external affairs, internal security, and the public service', and power to take control 'when necessary in the interest of public order, public faith, or good government'. Brief for UK mission at UN, 10 September 1969, FCO58/313.

25 Jakeway to Secretary of State for Colonies, 15 December 1966, CO1036/1667.

26 The new constitution required the governor to ensure appropriate representation of the various communities' in his Executive Council (Lal 2006: 1xiv). He now appointed three Fijians, six Europeans (three of them officials) and only one Indian who had been elected to the Legislative Council by mostly Fijian votes.

2711 January 1968, FCO 32/24. Jakeway's comments on the NFP were mainly negative. 
'undemocratic, iniquitous, and unjust' and called for a new conference. ${ }^{28}$ The NFP then commenced a long boycott of the Legislative Council, just as the UN again took Britain to task for allegedly mismanaging Fijis decolonisation. ${ }^{29}$ At public rallies and in the Hindi press supporting the party, there were renewed declarations that, despite opposition from Britain and the Alliance Party government, the UN would soon send an inspection team to Fiji. ${ }^{30}$

In by-elections for the vacant seats, in September 1968, the NFP waged a more aggressive campaign than before with the aid of two Fijians of high traditional rank. Their presence, speakers proclaimed, showed that not all the chiefs were with the Alliance Party. There were declarations that the constitution must be 'smashed' and denigration of the paramount Fijian chiefs (Mara and three of his Fijian colleagues in government) and European political leaders and business interests. The British rulers, Patel alleged, were resolved to perpetuate a European-dominated colonialist government. There was much anti-European rhetoric and stress on the need for Indian racial unity and denouncement again of Indian opponents for betraying their race (see Alley 1976: 235-59; Norton 1990: 98-102; Lal 1992: 203-06). Although indigenous Fijians were not to vote, there were attempts to win their favour by proposing that Fiji be made a republic with a Fijian head of state, and they were urged to unite with Indians against a shared oppression under the heel of the Europeans (Norton 1990: 97-100).

Winning back all seats with increased majorities was a pyrrhic victory for the NFP. Its attacks on the chiefs, together with the failure of Ratu Mara's strenuous personal campaigning, provoked an aggressive Fijian backlash that compelled the radicals to come to terms with dangers and constraints in the domestic political arena. There were marches and rallies in the towns, tacitly approved by Mara, directed against the Indian leaders and, for many marchers, against Indians in general. Before Mara and fellow chiefs subdued them, the protests came close to sparking widespread

28 Legislative Council Debates, 1 September 1967: 612. See also Alley 1976: 234-35; Lal 1992: 201. In the preceding months, the NFP had reportedly settled well into the role of 'opposition' and both parties had become 'increasingly anxious to present a public image of concern with national, not sectional or racial interests'. Acting governor Lloyd to Fairclough, 15 Sept. 1967, FCO32/21.

29 'The situation with regard to the implementation of the Declaration on the Granting of Independence to Colonial Countries and Peoples: Fiji.' The Yearbook of the United Nations 1967: 659-64.

30 Patel's speech at a rally at a Hindu temple. 1967. Jagriti (Nadi), 28 September; Editorial. 1967. Jagriti (Nadi), 30 September. 
violence. As Brij Lal has observed, 'The 1968 by-elections changed the political dynamics of Fiji' (Lal 2006: lxix). The genie of aggressive indigenous nationalism had been released, weakening the Indians' political resolve, encouraging them to conciliation, and strengthening the Fijian conviction of entitlement to power. Though failing to win an Indian seat, Mara made political gains from the aftermath of the elections. But there was, too, a shocked recognition by him and his political colleagues that a catastrophe had been narrowly averted.

The changed NFP mood was also influenced by a shift of advantage to Ratu Mara in the international political arena. In personal meetings commencing late in 1967, he persuaded the government of India to recognise Fiji's difficulties and to sympathise with his cautious and gradualist approach to constitutional reform. India began late in 1968 to urge the UN to moderation on the Fiji question. Several months before the by-elections, two official emissaries from India, reciprocating Mara's visit to New Delhi, had met with NFP leaders. They had criticised the boycott and urged the NFP leaders to seek an extension of cross-voting and a reduction of seats for General Electors rather than continue to press for a common franchise. ${ }^{31}$ They advised that some UN members were already moderating their position on Fiji and that the NFP leaders should work with their Fijian counterparts to achieve independence from Britain as soon as possible, and perhaps after that return to their common roll quest. $^{32}$

Patel and Mara had begun private discussions soon after their separate meetings with India's emissaries. The talks were suspended as the byelections drew near but were resumed soon after the Fijian protest crisis with the encouragement of another official emissary from India. The urgings of the Indian government men and the trend to moderation at the UN, encouraged by India, influenced the NFP leaders' efforts to reach agreement with the Alliance Party. In the mid-1960s, when UN pressure on the UK was strongest, Indian leaders had been sharply divided between a majority demanding radical change and a minority joining with Fijians and Europeans in a conservative approach to electoral reform. By the end of the decade, the militants themselves had become moderates favouring compromise.

31 Visit of Indian government officials 1967-1969, NAF, C163/16. See also Norton 2004: 166-67.

32 Karam Ramrakha, a party principal at that time. Personal communication, 19 July 2003. 
Talks between the parties in Suva and at a conference with British officials in London led to the granting of independence to Fiji in October 1970 (see Alley 1976: 352ff, 380ff; Lal 2006: lxxii-lxxix; Norton 2004: 175-82; Scarr 2009: 165-88; Vasil 1972). The London conference of April-May 1970 presented a striking contrast to that of 1965, with political leaders now meeting in a mood of relaxed accord. The NFP leaders' willingness to temporarily shelve their common roll call and to accept a degree of Fijian political precedence was the most important factor in this, together with their suggestion that Fiji proceed to independence under Mara's government. ${ }^{33}$ These concessions might have been more difficult to make but for a new NFP president, the younger and Fijiborn Siddiq Koya, appointed following Patel's death soon after the start of the Suva talks. Also important for the rapprochement was the shared concern that the party conflict had almost brought a catastrophe upon Fiji. ${ }^{34}$ Mara's growing confidence in leading routine government, together with his strengthened success in the international arena, made him more open to conciliatory dialogue. In return for the NFP concessions, the Alliance leaders agreed to restoration of parity of elected representation of Indians and Fijians in a lower house of parliament, and a small reduction of seats for General Electors. Although all seats continued to be ethnically reserved, the proportion based in multiethnic electorates was increased. To Indian critics of the NFP's moderate turn, Koya replied that 'party interest [in a common roll] has been subordinated to the interest of the nation'. A common roll, he now insisted, can only be introduced 'if a significant number of Fijians accept it'. ${ }^{35}$

The dialogue in Suva had been conducted in camera by political elites who feared that to put their agreements to a popular test in elections before going to London would risk a renewal of ethnic polarisation that might break the accord. It was a major failing of the decolonisation process that it was not accompanied by a balanced development of multiethnic political organisation. This was at least partly because political competition

33 The Council of Chiefs was to control appointments to eight of the 22 seats in an upper house of parliament, with power to veto legislative proposals affecting specifically Fijian interests; the other senators would be nominees of the prime minister and the leader of the opposition.

34 Mara told the press after the London conference that the 'animosity' arising in the 1968 byelections spurred greater efforts to find agreement 'between the races' because 'we realised we were right on the brink of disaster if we were not very careful'. 'Need to plug for all races says chief minister'. 1970. Fiji Times, 7 May: 3.

35 'Patience on common roll'. 1970. Fiji Times, 13 July: 3. 
remained tied to the most ethnically divisive issue: the NFP's demand for radical electoral reform at a time of heightened indigenous Fijian feelings of insecurity and suspicion. In their confidential Suva talks, the leaders finally broke from that impasse. But by then ethnic opposition in political organisation had been set for many years to come; the major cause of the fragility of democratic government in Fiji.

During the 1960s, the NFP held only the nine Indian communal seats and it continued after independence to have only very weak indigenous Fijian support and less from General Electors. The Alliance Party maintained the allegiance of a large majority of Fijians and in the first postcolonial elections in 1972 attracted 24 per cent of Indian communal votes. But the party was soon challenged by an extremist Fijian group, which led it to lessen efforts to win Indian favour, and in subsequent elections the Alliance Party drew no more than 16 per cent of their votes.

\section{Counterfactual questions}

The NFP's common franchise campaign was so greatly at odds with the possibilities for political success that one must ask why it was pushed so strongly. There was, for several years, the hope that Britain's new Labour government, especially in the face of UN pressure and the strength of Indian support for the NFP, would override European and Fijian resistance to radical reform. More significant, however, was the NFP's impact on Indian political and social consciousness. The vibrant public rallies with combative oratory engendered feelings of strength and pride set against a colonial regime seen as supporting European power and privilege. These sentiments sustained the party's aggressive momentum despite its very weak prospects for success in both the domestic and international arenas.

The manner in which the NFP leaders pursued their radical reform goal was unwise given the strength of ethnic disparities, the very limited Fijian experience of electoral politics and their anxiety over the prospect of British rule ending. Patel, who dominated the NFP, maintained an intellectualist approach to reform, arguing the logical merits of a common franchise for building a new nation but paying little heed to the nature 
of the Fijian resistance. In this vision he was encouraged by doctrinaire principles of the UN declaration of December 1960, which demanded the ending of colonial rule 'without conditions or reservations'. ${ }^{36}$

While ostensibly aiming to promote political integration, the push for a common franchise contributed to ethnic tension by calling for the abolition of ethnic distinctions in political representation and by the NFP's emphasis on uniting Indians and attacking Europeans and leading Fijian chiefs whose alliance Fijians had long viewed as protective. An NFP principal, speaking on the outcome of the 1970 conference, acknowledged the danger in his party's failure to understand the Fijian fears. He stressed the importance of advice from the two Fijians who joined the party's leadership early in 1968:

If they had not warned us about the deep undercurrents and the deep thinking of the Fijian people on many matters ... we might easily have taken the wrong path, and the two parties, locked ... in bitter confrontation, might have taken a path which may have been disastrous to the country. ${ }^{37}$

Brij Lal has pondered on how Fiji's decolonisation might have been better conducted, how different decisions might have been made and different paths taken. Pursuing such questions need not be the fruitless 'parlour game' famously derided by historian E.H. Carr (1987: 97) but can aid insight into the nature of constraints and potentialities at critical historical moments. A number of scholars, during the last 20 years, have argued persuasively for the value of counterfactual thinking, particularly about political events. They stress the importance of rigour in relating hypothetical alterations of past actions to known contextual constraints and realistic possibilities, and the need to avoid personal values or interests determining the conjectures (see especially Tetlock and Parker 2006: 14-44; for a critical review of the literature, see Evans 2014). These studies encourage me to consider afresh some 'might have beens' of Fijis late colonial history, especially the possibility that existed for a stronger and more balanced development of interethnic cooperation in political parties.

36 'Declaration on granting independence to colonial countries and peoples'. In The Yearbook of the United Nations 1960: 44-50. The original UN statement on colonialism qualified its call for selfgovernment by recognising the need to take account of 'the particular circumstances of each territory and its peoples and their varying stages of advancement'. United Nations Charter, June 1945, Chapter 11, Article 73, 'Declaration Regarding Non-Self-Governing Territories'.

37 Karam Ramrakha, Fiji Legislative Council Debates, 17 June 1970: 228. 
Commentators on Fijis political history, including Lal, have often attributed Fiji's difficulties substantially to an ethnically divided electoral system and have maintained that common electoral rolls and elimination of the ethnic reservation of parliament seats would have encouraged multiethnic collaboration on the basis of shared interests. While I certainly agree that this reform was desirable as a long-term objective, it is important to recognise that a common franchise is not a panacea for ethnic division in political life. ${ }^{38}$ Shared material interests upon which interethnic unities might be built can also foster ethnic competition for scarce resources and a politics of ethnic patronage.

The prospect for the introduction of a common franchise in 1960s Fiji was minimal. It would be unrealistic to suggest that Ratu Mara and his Alliance Party colleagues could have been persuaded to make a major concession to the NFP call for this reform or that the British government might, in the prevailing political situation, have insisted on it. Given the strength of Fijian (and European) defensive hostility, and the British fears of instability and violence, these must be rejected as implausible counterfactuals. ${ }^{39}$ Among the Fijian leaders, Mara was by far the most able and the most progressive in social and political vision. In the 1950s, he had advocated multiethnic schooling and a common franchise for town government. ${ }^{40}$ But as the preeminent leader in the 1960s, he was constrained by the deep conservatism of colleagues in the Fijian Association and the Great Council of Chiefs and was himself averse to a common franchise at national level where Fijian interests were seen to be potentially at risk.

A more plausible counterfactual is an NFP willingness to moderate their common roll quest early in the decolonisation process. ${ }^{41}$ This would have resulted in a less antagonistic and mistrustful opposition between the parties and might have opened the way for more interethnic cooperation on both sides. An attempt to continue dialogue in Suva in 1965 by discussing the electoral issue in a flexible way, signalling the possibility of compromise, might have encouraged at the first London conference

38 Trinidad and Guyana, societies with which Fiji is often compared, demonstrate this with their strong tendencies over many years to ethnic polarisation in electoral competition.

39 Fijians sympathetic to the call for a common franchise at that time were a tiny tertiary-educated minority.

40 A common franchise was introduced for town boards in 1967, and for Suva and Lautoka municipal councils in 1970 .

41 The common franchise question was not an important issue in the 1963 Legislative Council elections. 
a mood more conducive to an outcome acceptable to the party. This in turn might have favoured more interethnic collaboration in the 1966 elections instead of the aggravation of the ethnic political divide that did occur.

It is true that pressures and incentives for the NFP to remain firm in its call for the common franchise were strong. Aggrieved over the outcome of the 1965 constitutional conference, the NFP leaders remained hopeful of support in the international arena and they were determined to preserve their dominance of Indian leadership to persuade that support. The 'common roll' cry acquired powerful symbolic force, iconic of legitimate Indian leadership against alleged injustice and insecurity under colonial rule. To soften the demand in the Suva talks early in 1965 might have been seen to discredit the party's image as fearless champion of Indian rights. ${ }^{42}$

Yet there were moments of internal conflict that indicate the potential for the NFP to have modified its approach. There was, toward the end of 1967, strong support within the leadership for ending the boycott of the Legislative Council, ${ }^{43}$ and after the meeting with India's emissaries early in 1968, there was again dissension about the boycott. ${ }^{44}$ Moreover, popular Indian sentiment in support of the push for a common franchise was not comparable to the strength of indigenous Fijian sentiment against it. For most Indians, conditions for leasing Fijian-owned land and access to other economic opportunities were more important issues.

The NFP might have chosen to put greater emphasis on economic and social development issues, including those of special concern to indigenous Fijians and those cutting across the ethnic divide, matters that the leaders often did address at public rallies. Perhaps, had the NFP given more attention to those matters and softened its position on electoral reform, the colonial governor might, with Mara's assent, have established

42 In Alley's words, 'The stridency with which [the NFP] began propounding the need for a common roll was due, at least in part, to fears of Indian communal disunity at a time when it could be least afforded' (1976: 160).

43 This was overruled by Patel (Alley 1976: 327-28).

44 Fiji Political Intelligence Committee, report for February 1968. NAA, A1838/346 TS699/9/1 Part 2. 
the coalition government he had wanted following the 1966 elections. ${ }^{45}$ This could have further strengthened efforts to build multiethnic cooperation for subsequent elections.

In this hypothetically different course of political events from an earlier moment in decolonisation, greater progress toward a true common franchise (multiethnic electorates with non-reserved seats) might have been made in preparation for independence. It is ironic that the traumatic experience of Fijian intimidation provoked by the aggressive push for radical reform contributed to the weakening of the Indian leaders' interest in the issue. When in 1975 Prime Minister Ratu Mara rejected the recommendation of an official inquiry for the introduction of some common roll electorates without ethnically reserved seats, the NFP leaders did not strongly protest. ${ }^{46}$

In 2013, long after Indian leaders had ceased to push for it, a regime backed by the almost exclusively indigenous Fijian army imposed a common franchise in the context of a greatly decreased Indian population, ${ }^{47}$ a resolve to suppress Fijian ethnic nationalism, and the need for a selfvalidating nation-building mission. Once the major objective of radical Indian politicians and anathema to the Fijians, a common franchise now has central place in the ideology of a mainly indigenous Fijian government.

\section{Archives consulted}

National Archives of Australia (NAA)

National Archives of Fiji (NAF)

National Archives (Kew)

Record of the Dominions Office (DO)

Records of the Colonial Office (CO)

Records of the Foreign and Commonwealth Office (FCO)

45 I don't discount the possibility that Jakeway might have overruled Mara's objection to powersharing despite the hostility and mistrust on the part of Mara and Falvey against Patel at that time, although I think that was very unlikely. In old age, Mara told an interviewer that he regretted not having agreed to share power in government with Patel: 'Patel was an intelligent man. He would have worked along' (Hancock 2003: 34, cited in Lal 2011: 102).

46 The inquiry fulfilled a requirement in the 1970 constitution, inserted in compensation for the NFP agreeing to temporarily shelve their common franchise agenda (Lal 1992: 221-24). Not until a new constitution in 1997 were some multiethnic electorates without reserved seats introduced, although ethnic electorates remained in the majority.

47 The 2007 census reported that Indians were approximately 37 per cent and Fijians approximately 57 per cent of Fijis population. 
Pacific Manuscripts Bureau, College of Asia and the Pacific, The Australian National University

Papers of A.D. Patel

\section{References}

Alley, Roderic. 1976. 'The development of political parties in Fiji', $\mathrm{PhD}$ thesis, Victoria University, Wellington.

— 1986. 'The emergence of party politics'. In Politics in Fiji, edited by Brij V. Lal, pp. 28-51. Sydney: Allen \& Unwin.

Carr, E.H. 1987 [1961]. What is History? 2nd edition, edited by R.W. Davies. Harmondsworth: London: Penguin Books.

'Declaration on granting independence to colonial countries and peoples'. In The Yearbook of the United Nations, 1960: 44-50. Online: cdn. un.org/unyearbook/yun/chapter_pdf/1960YUN/1960_P1_SEC1_ CH5.pdf (accessed 7 March 2017).

'Declaration on independence for colonial countries and peoples: The situation with regard to the implementation of the Declaration on Granting Independence to Colonial Countries and Peoples'. In The Yearbook of the United Nations, 1963. Online: cdn.un.org/ unyearbook/yun/chapter_pdf/1963YUN/1963_P1_SEC3_CH3.pdf (accessed 7 March 2017).

Editorial. 1967. Jagriti (Nadi), 30 September.

Evans, Richard J. 2014. Altered Pasts: Counterfactuals in History. Harmondsworth: Abacus.

Hancock, Kathleen. 2003. Men of Mana: Portraits of Three Pacific Leaders-Ratu Sir Kamisese Mara, Afioga Va'ai Kolone, Sir Robert Rex. Wellington: Steele Roberts.

Lal, Brij V. 1979. 'Fiji girmitiyas: The background to banishment'. In Rama's Banishment: A Centenary Tribute to the Fiji Indians 1879-1979, edited by Vijay Mishra, pp. 12-39. Auckland and London: Heinemann Educational Books. 
1992. Broken Waves: A History of Fiji in the Twentieth Century. Honolulu: University of Hawai'i Press.

- 1997. A Vision for Change: AD Patel and the Politics of Fiji. Canberra: National Centre for Development Studies, The Australian National University.

- - (ed.). 2006. British Documents on the End of Empire, Series B, Volume 10: Fiji. London: The Stationery Office.

- - (ed.). 2011. A Vision for Change: Speeches and Writings of AD Patel, 1905-1969. Canberra: ANU E Press. Online: press.anu.edu. au?p=152161 (accessed 21 December 2016).

Lowenthal, David. 1985. The Past is a Foreign Country. Cambridge: Cambridge University Press.

Meller, Norman and James Anthony. 1968. Fiji Goes to the Polls: The Crucial Legislative Council Elections of 1963. Honolulu: East-West Center Press.

Mishra, Vijay (ed.). 1979. Rama's Banishment: A Centenary Tribute to the Fiji Indians 1879-1979. Auckland and London: Heinemann Educational Books.

'Need to plug for all races says chief minister'. 1970. Fiji Times, 7 May: 3.

Norton, Robert. 1990. Race and Politics in Fiji, 2nd ed. Brisbane: University of Queensland Press.

—_. 2002. 'Accommodating indigenous privilege: Britain's dilemma in decolonising Fiji'. Journal of Pacific History, 37(2): 133-56. DOI: $10.1080 / 0022334022000006574$.

—_. 2004. 'Seldom a transition with such aplomb: From confrontation to conciliation on Fiji's path to independence'. Journal of Pacific History, 39(2): 163-84. DOI: 10.1080/0022334042000250715.

—. 2015. 'Brij Lal's biography of A.D. Patel-A Vision for Change: AD Patel and the Politics of Fiji'. Fijian Studies: A Journal of Contemporary Fiji, 13(1): 17-30.

Patel's speech at a rally at a Hindu temple. 1967. Jagriti (Nadi), 28 September. 
'Patience on common roll'. 1970. Fiji Times, 13 July: 3.

Scarr, Deryck. 2009. Tuimacilai: A Life of Ratu Sir Kamisese Mara. Adelaide: Crawford House Publishing.

Tetlock, Philip E. and Geoffrey A. Parker. 2006. 'Counterfactual thought experiments: Why we can't live without them $\&$ how we must learn to live with them'. In Unmaking the West: 'What-if?' Scenarios that Rewrite World History, edited by Philip Tetlock, Ned Lebow and Geoffrey A. Parker, pp. 14-44. Ann Arbor: University of Michigan Press.

Tetlock, Philip, Ned Lebow and Geoffrey A. Parker (eds). 2006. Unmaking the West: 'What-if?' Scenarios that Rewrite World History. Ann Arbor: University of Michigan Press.

'The situation with regard to the implementation of the Declaration on the granting of independence to Colonial Countries and Peoples: Fiji.' In The Yearbook of the United Nations, 1966: 578-81. Online: cdn. un.org/unyearbook/yun/chapter_pdf/1966YUN/1966_P1_SEC3_ CH2.pdf (accessed 7 March 2017).

'The situation with regard to the implementation of the Declaration on the granting of independence to Colonial Countries and Peoples: Fiji.' In The Yearbook of the United Nations, 1967: 659-64. Online: cdn. un.org/unyearbook/yun/chapter_pdf/1967YUN/1967_P1_SEC3_ CH2.pdf (accessed 7 March 2017).

Vasil, Raj. 1972. 'Communalism and constitution-making in Fiji'. Pacific Affairs, 45(1): 21-41. DOI: 10.2307/2755259. 
This text is taken from Bearing Witness: Essays in honour of Brij V. Lal, edited by Doug Munro and Jack Corbett, published 2017 by ANU Press, The Australian National University, Canberra, Australia. 